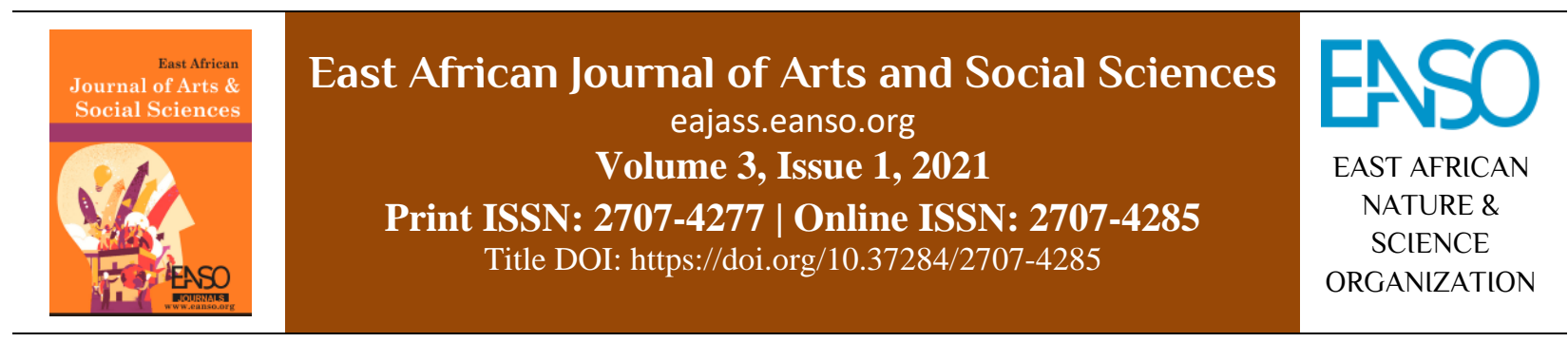

Original Article

\title{
Will Kymlicka's Idea of Multicultural Citizenship Rights and the Nigeria Federation
}

\author{
Mark Omorovie Ikeke, $P h D^{1 *}$ \\ ${ }^{1}$ Associate Professor, Department of Religious Studies and Philosophy, Delta State University, PMB 1 Abraka, Nigeria. \\ *Correspondence email: Ikeke7@yahoo.com.
}

Article DOI: https://doi.org/10.37284/eajass.3.1.370

\section{Article history: ABSTRACT}

02 August 2021 Will Kymlicka is a Canadian political philosopher using his Federal Canadian society as a basis argued for the recognition of minority rights, in what he calls

Keywords: multicultural citizenship. His idea is that the claims to self-determination or

autonomy, protection of a distinct cultural language and special representation need

Kymlicka, to be accommodated. National minorities should not be forced to integrate as this

Multicultural, can lead to violence. Without recognizing the group rights of ethnicities, they will

Citizenship, be culturally disadvantaged. Using Kymlicka's idea in an analytical manner, this

Rights, paper applies his theory to the Nigerian federation. Despite many years of operating

Rights, so-called federalism, the system is be-devilled by ethnic agitations, violent

Nigeria, militancy, youth restiveness, and many other social ills. The paper theorizes that

Federation failure to operate a true federal structure that recognizes and fully accommodates minority rights is a key problem responsible for these social ills. Nigeria is a weak and troubled federation where the rights of national minorities are often neglected, suppressed and denied. When it comes to language, the languages of the three dominant groups in terms of population are privileged over others. Representations in both state and federal establishments are often in favour of dominant ethnic groups. The cries for autonomy and restructuring of the federation are often not heeded. The paper argues that accommodating the rights of minorities can help them integrate and foster a sense of equality in a true federation. It also argues that beyond restructuring, ethical leadership is needed to move the federation forward. The paper finds and concludes that some ideas of Kymlicka can help in creating a peaceful and unified federal Nigeria

APA CITATION

Ikeke, M. O. (2021). "Will Kymlicka's Idea of Multicultural Citizenship Rights and the Nigeria Federation. East African Journal of Arts and Social Sciences, 3(1), 128-136. https://doi.org/10.37284/eajass.3.1.370 


\section{CHICAGO CITATION}

Ikeke, Mark Omorovie. 2021. "Will Kymlicka's Idea of Multicultural Citizenship Rights and the Nigeria Federation". East African Journal of Arts and Social Sciences 3 (1), 128-136. https://doi.org/10.37284/eajass.3.1.370

HARVARD CITATION

Ikeke, K. (2021) "Will Kymlicka's Idea of Multicultural Citizenship Rights and the Nigeria Federation", East African Journal of Arts and Social Sciences, 3(1), pp. 128-136. doi: 10.37284/eajass.3.1.370.

\section{IEEE CITATION}

K. Ikeke, "Will Kymlicka's Idea of Multicultural Citizenship Rights and the Nigeria Federation", EAJASS, vol. 3, no. 1, pp. 128-136, Aug 2021.

\section{MLA CITATION}

Ikeke, Mark Omorovie. "Will Kymlicka's Idea of Multicultural Citizenship Rights and the Nigeria Federation". East African Journal of Arts and Social Sciences, Vol. 3, no. 1, Aug 2021, pp. 128-136, doi:10.37284/eajass.3.1.370.

\section{INTRODUCTION}

The question of citizenship rights is a crucial one in Nigeria. It is part of the national question. It is crucial because without recognition of citizenship rights one can be deprived of the benefits that accrue to citizens and access to the good life and public good. Taylor (1992) remains one of the foremost political philosophers who have argued for a politics of recognition. Citizenship rights have always been a serious challenge in Nigeria from her independence from the British in 1960. To a certain degree, the civil war of the 1960s was fought over citizenship rights. Ojukwu Odumegwu and many other Igbo people felt marginalized in the Nigerian federation and fought the civil war to assert their citizenship rights and also to secede from the Nigerian federation.

Many other agitations and uprisings in the federation are partly because of the issue of citizenship rights. The fact that there are ethnic agitations and tensions and democratic questions over citizenship rights in the Nigerian nation is attested to many scholars such as Mustapha (2004), Falola (2004), Alubo (2006), and Dukor (2003). Many voices such as those of Tunde Bakare, Atiku Abubaker, Ibrahim Babaginda, Rauf Aregbesola, Ekweremandu, Emeka Anyaoku, Soludo, Bishop Matthew Kukah, Pro National Conference Organization (PRONACCO), Afenifere, Professor Oloyede, and many others have asserted that Nigeria needs restructuring. Restructuring means different things to different people. But one fact is clear and that is, it is not well with the Nigerian federation as presently structured and many feel marginalized as they are deprived of the benefits of citizenship and access to the good life that Nigeria should provide. The militancy in the Niger Delta partly arises from the fact that both ethnic and militant groups argue that their rights to more revenue from oil and real fiscal federalism is not being operated in Nigeria. Ethnic nationalities and also ethnic militias especially the Odua People's Congress, Indigenous Peoples of Biafra, Movement for the Actualization of the Sovereign State of Biafra, etc are all aimed in one way of the other at acquiring more citizenship rights. Places like Jos, Kano, Ijebu-Ode, Lagos and other cities have been bedevilled by indigene-settler problems. Some claim that they are native of those places and accuse other Nigerians that come to settle as not entitled to some rights and resources. It is true to state that in a true federation, all citizens can settle in any part of their countries and be entitled to the same basic rights.

The recent call by some northern youths that Igbo people should leave the north and the call by some Igbo groups that people from the north should leave the South East are all questions that bother on citizenship rights. Various groups such as the southeast governors have all called for restructuring of the Nigerian federation. The central argument of this paper is that various ethnic groups have been marginalized in the Nigerian federation. The paper argues that individuals and ethnic groups should be recognized to exercise their ethnic cultures and right to language, education, etc while at the same time sharing in national citizenship. One's ethnic identity and participation in ethnic culture should not be seen as being in conflict with national citizenship. Hoffman and Graham (2009) correctly propound that a person's sense of identity is informed by their 
cultural traditions, language and beliefs and they ought to be respected. The paper will look at the issue through the lens of the political philosophy of the Canadian political philosopher, Will Kymlicka.

\section{Analysis of Concepts}

The following concepts of multiculturalism, citizenship and federation inform this paper. Sarah (2017) opines that multiculturalism deals with the issue of how to manage religious and cultural diversities in the context of western liberal democracies. The term has also come to be used as Sarah (2017) citing Glazer, Hollinger and Taylor note to include: "the moral and political claims of a wide range of marginalized groups, including African Americans, women, LGBT people, and people with disabilities." Multiculturalists often argue against the idea of cultures melting into one rather they favour various groups maintaining their cultural identities and norms while being part of the larger group. Rodrigues (2017) asserts that: "The term 'multiculturalism' is sometimes used to describe a condition of society; more precisely, it is used to describe a society where a variety of different cultures coexist." Culture, as is understood, refers to the entirety of a people's way of life. It includes their customs, religious and spiritual beliefs, norms, food systems, agricultural systems, ceremonies, political institutions, etc. Nothing about the way of life of a people is excluded from culture. That being the case, multiculturalism refers to the existence of many cultures or a plurality of cultures. Multiculturalism has to do not just with their existence but how they co-exist and relate with one another. Pierik (2013) avers that: "From the mid-1990s onward, cultural diversity and multiculturalism has become a subject of major interest in the social sciences and philosophy" (p.3470). The author just mentioned notes that it is a multifaceted movement with various shades of meaning such as issues of migrant workers in Europe; Quebec separatism in Canada; the issue of slavery and the place of African American in the United States; sociologically it is cultural pluralism, government policies on how to treat immigrants and exceptional provisions for them, and it could also be a statement of how society should be organized in the midst of diverse cultures. As Johari (2009) puts it multiculturalism pays attention to the need of stigmatized and neglected groups in their separate and distinct identity. These groups he notes don't want to be treated as inferior citizens. They want recognition of their distinct cultural identity while sharing the values of the larger group. Johari (2012) in another work states the essential features of multiculturalism as preservation of distinct cultures, value pluralism, and cultural groups is entitled to social justice, and differentiated citizenship.

Chaturvedi (2006) writes that citizenship involves enjoying certain rights and privileges and contributing one's obligations to the state which include participation in the affairs of the state. For Abercrombie, Hill \& Turner (2000) it implies access to rights and powers in the state and these rights include civic, political and socio-economic rights. Bellamy (2008) notes that: it has to do with membership, belonging and participation in the political and socio-economic life of a community, of which this community has a right to regulate the members who share solidarity among themselves.

Now that multiculturalism and citizenship have been defined it is imperative to define the term, multicultural citizenship. Multicultural citizenship is the recognition that the citizens of a nation can share and identify with their native cultural communities while participating in the national life of the nation. It is not contradictory to feel belonging to an ethnic unit and at the same time share in national affiliations. Rodrigues (2017) rightly enunciates that: multicultural citizenship implies that: basic rights of citizenship should be protected, state laws should protect culture, the normative character of culture, individuals have a strong interest in culture that should not be ignored, and policies to preserve differentiated citizenship.

The idea of multicultural citizenship rights is a recent one in the history of western philosophical political thought. In ancient Greece where western philosophy originated, only adult males were considered to be citizens of the political community. Slaves were not considered to be citizens, so also were women who are considered to be irrational as Faulks (2000) indicates. Bellamy (2008) correctly notes that citizenship was limited to those of noble birth and the wealthy and there were often tensions in ancient Greece over this. Faulks (2000) has shown that in ancient Rome the concept of 
citizenship also underwent various evolutions. He notes that at the time of the republic it has to do with political participation; at the time of imperial Rome, it was extended to the people of the empire to exercise political control over them, and eventually citizenship came to simply imply rule of law; with the emphasis on citizenship diminishing when the Roman Empire fell. In the middle ages, the emphasis on citizenship diminished as the church gained more prominence than the political community.

In Machiavelli, citizenship was for the protection of the people's interest in the republic as Faulks (2000) avers. In the United States for many years blacks and many other people of colour and women were denied citizenship rights. Minority rights were not recognized and they were not even allowed to integrate. Minorities were discriminated against and considered to be second-class citizens. In the history of Nigeria, the colonialists did not consider Nigerians as citizens entitled to equal rights as British citizens. In African traditional societies, not all were treated as citizens. Slaves and outcasts were deprived of full participation in society. Women and female children were discriminated against and deprived of many rights such as inheritance rights, education rights, etc. Modern notions of citizenship that highlighted equality have been helped by the writings of Thomas Hobbes, John Locke and the events of the French Revolution of 1789 that defined the rights of man.

The point that needs to be said is that the notion of citizenship has evolved over time. The intention above is not to do detailed historical documentation of the evolution of the concept of citizenship. That is beyond the scope of this work. It will suffice to note that:

Two dominant strands or traditions of rights and citizenship can be seen to have developed over these periods: civic republicanism, characterized by the ideas of common good, public spirit, political participation and civic virtue; and liberal citizenship with an emphasis on individual rights and private interests. The Marxists and feminists have criticized both these traditions as exclusionary and have suggested radical changes in the theory and practice of citizenship. Similarly, cultural pluralists, radical pluralists and civil society theorists have offered alternative ways of thinking about citizenship and rights. (p.132).

The above suffices just to show that the notion of citizenship has evolved and that the present argument for multicultural citizenship is a further expansion of the idea of citizenship. A detailed discussion of the historical evolution of the citizenship concept can be found in Roy (2008), Aleinikoff and Klusmeyer (2001), Faulks (2000), Beiner (1995), Shafir (1998) and Bellamy (2008).

The paper is concerned with multicultural citizenship rights in the Nigerian federation. What is a federation? Chaturvedi (2006) cites Dicey saying: "a federal State is a political contrivance intended to reconcile national unity and power with the maintenance of "state rights" (p. 116). As for the Nigerian federation, it seems to be a failed federation. It operates as a centralized unitary state. The states and regions lack true power. There is hardly any book that deals with the Nigerian federation that you read that are not inundated with complaints and misgivings about the Nigerian federation. A look at the titles of writings on the Nigerian federation clearly reveals this reality. Take the following titles for instance: (1) The federal character principle and the search for national integration by Ayoade (1998), (2) Federalism, interethnic conflicts and the northernization policy of the 1950s and 1960s by Olawale (1998), (3) On the ethics of ethnic balancing in Nigeria: Federal character reconsidered by Uroh (1998), (4) The politics of federalism in Nigeria by Elaigwu (2005). The Nigerian federation is troubled by a lot of problems that cannot all be mentioned here. It suffices to note that managing the various ethnic groups and building national integration is a major issue in the land. Perhaps the idea of multicultural citizenship can be helpful.

\section{Will Kymlicka' Theory of Multicultural Citizenship}

Kymlicka who is presently a professor of Philosophy at the Queen's University at Kingston was born in 1962. He received a BA in Philosophy and Politics from Queen's University in 1984 and a D.Phil in Philosophy from Oxford University in 
1987. He is a Canadian Political Philosopher who has written much on multiculturalism, minority rights, animal rights, etc. Among the books written by him are: his 1989 book on Liberalism, Community and Culture; his 1990 work on Contemporary Political Philosophy, and his 1995 book on Multicultural Citizenship. He has also edited some books, Citizenship in Diverse Societies edited in the year 2000 with Wayne Norman. He has many other works to his credit.

The classical idea of Kymlicka (1995) comes in his work, Multicultural Citizenship: A Liberal Theory of Minority Rights. He states there are two types of multiculturalism- multinational states and polyethnic states. The first refers to states with a national minority that has a distinct language, culture and territory; while the latter refers to a state that has experienced an immigrant population, this immigrant population has a language and culture but no claim to the territory. National minority group was conquered or came into the state through agreement. For a country like Canada, Kymlicka (1995) states that it is both a multinational and polyethnic state. It has both an immigrant population such as that of the British and French, and the Inuit national group. He notes that national groups seek self-determination or autonomy within a federal structure; while ethnic groups desire that their culture and language should be recognized as they integrate into the nation. Both national groups and ethnic groups seek special representation at the national level.

Kymlicka (1995) worries that liberals are often worried that granting special concessions to national or ethnic groups offends against democracy and is illiberal as democracy requires treating people identically as one. For Kymlicka the request for special concessions is not illiberal rather it enables these groups to integrate into the main group and not that they want to be different. He notes that when Orthodox Jews seek exemption from military dress for them to wear their yarmulkas it is because they want to be part of the army. He does not overlook the limitations of multicultural citizenship; for he notes that when national minorities argue for selfgovernment this can hinder common citizenship and patriotism. This does not mean national minorities have no right to self-government, rather we need a theory that recognizes their rights and how multiple national groups can exist within a single political community.

Kymlicka (2010) notes that the question of minority and group rights is an important one for political philosophy. He also asserts that group rights are not against liberalism rather they can be defended within the framework of democratic and justice values. On the origin of what Kymlicka (2010) calls liberal multiculturalism, he writes that:

Liberal multiculturalism emerged out of the liberal-communitarian debate that dominated Anglo-American political philosophy in the 1980s. Communitarians had criticized liberalism for their too individualistic and atomistic, and for being incapable of recognizing the importance of communal and cultural attachments. Liberals responded that communitarian claims about the 'embeddedness' of individuals within communities or cultures were exaggerated, and risked imprisoning people in identities and practices they no longer endorsed.

Much of this debate was pitched at an abstract level, focusing on theories of the self and the good life. But it was quickly applied to a number of policy issues, including questions about the rights of ethnic minorities. Communitarians argued that traditional liberal theories of individual rights were unable to protect such minorities from assimilationist pressures; liberals responded that communitarian demands for 'group rights' were a threat to individual liberty. (p. 378)

It is important to note that many nations that emerged out of colonialism, they began to embark on a monolithic nation-building project. This project required that all the various ethnic groups of people have to be integrated into one people which implies speaking one language, having one educational system, one judicial system, and erasing anything that fosters ethnic identity. All forms of ethnic identity such as self-government, cultural values have to be abolished in favour of the nation. Kymlicka argues that individuals can have legitimate interests in cultural belongings, as affirmed by the communitarians, and these should be protected if not there will continue to be tensions and conflicts in the nation. It is important to note 
that: "individual freedom is tied to membership in one's national group; and that group-specific rights can promote equality between the minority and majority" (Kymlicka 2010b, p. 270). The core thesis of Kymlicka (2004) who sees a convergence between western forms of nation-building and African countries as they all put pressures on minorities, is that nation-building projects should not suppress minority rights rather "justice in multiethnic countries will always require some balancing of nation-building and minority rights" (p. 71).

\section{Questioning the Nigerian Federation in the Light of Kymlicka}

Following Kymlicka's classification, Nigeria is a multinational state with major ethnic groups and minorities. The ethnic groups and minorities found themselves in this nation called Nigeria as a result of the amalgamation of the northern and southern protectorates by the British. That the rights of ethnic groups especially minorities have been denigrated in the Nigerian federation should not be in doubt. The non-recognition of ethnocultural rights such as autonomy, self-government, resource control, language rights, etc has precipitated various problems in the federation. In the Nigerian federation for instance the three languages of Yoruba, Hausa, and Igbo are often privileged over other languages. You can be examined in ordinary level examinations in these languages but there is no provision for the languages of the other nationalities. Some may argue that it will be too burdensome to have examinations in many other languages. The point that this paper makes is that this is a major challenge for the nation. Nationalities have a right to their language and since in a federation as Obafemi Awolowo affirms all nationalities are equal, then the language of one should not be privileged over others.

Many national minorities and even major national groups are arguing for self-government or autonomy in the Nigerian federation. A look through the ethnic declarations of groups like the Ijaw Youths (1998), the Ogoni people (1990), the Oron Indigenous Ethnic Linguistic Nationality (1999), etc show that they all want autonomy within the Nigerian federation. Self-determination is a right of all peoples. Following Kymlicka's thought, a formula has to be found where national multiple nationalities can live within a single political unit while respecting their autonomies. But as Nigeria has experienced, her federal system is unbalanced and needs restructuring.

Kymlicka's theory of multicultural citizenship like every other form of political theory should not be seen as a perfect one. A great weakness of multiculturalism as noted by Johari (2009) is that it can foster anti-nationalist tendencies and thus impede the realization of national integration. Other challenges that have been noted with regard to multiculturalism are that some ethno-cultural groups can be illiberal and have values that conflict with justice, equity and fairness. Hoffman and Graham (2009) note that: "What if a particular cultural tradition..." But what if a particular cultural tradition is hostile to liberalism? What if, for example, it holds that girls should be educated to fulfil a subservient role, limited strictly to the private sphere of the family? What if it advocates discrimination, or even violence, against adherents of other religions, or homosexuals, or different ethnic groups? These are questions raised by multiculturalism, an ideology that has emerged since the 1960s, but which stands in a complex relationship to older ideologies. (p. 340). The point that needs to be made here is that recognizing multicultural citizenship rights does not in any way mean that the particular values of a culture trump the national civic values. Every group is still subject to the national laws of the land. And cultural tendencies that do not accord with internationally recognized human rights instruments and the just laws of the land need to be reviewed.

Kymlicka has noted that recognizing multicultural rights is not illiberalism. Failure to recognize multicultural rights often leads to tensions, violence, and social instability in the state. Militant ethnic agitations in Nigeria have often led to violence and disruption in the production of oil and other economic products in Nigeria. Insecurity in the land is heightened by ethnic tensions and agitations. It is for the Nigerian state to find a way to recognize adequately minority rights and devise a formula for a balanced federation where all Nigerians and the ethnic groups they come from live in harmony.

An important aspect of African peoples and Nigerians that should not be neglected is the 
communitarian aspects. It was within their particular ethnic and cultural groupings that individuals found meaning and the purpose of life in pre-colonial African societies. They continue to a certain degree to find meaning in their cultures in the modern state. Communitarian philosophers have brought to light the importance of culture in the formation of people. This paper would love to agree with Kymlicka and Shapiro (1997) that there are legitimate interests that people have in their ethnocultural background that should not be ignored. The modern state including Nigeria cannot adequately accommodate and recognize as at yet the ethnocultural group membership of the various peoples of Nigeria. That is why there have continued to be ethnic agitations and uprising and the continuous call for restructuring and the cry of marginalization by many ethnic groups in the country. Nigeria must find a way to answers all the agitations for true federalism, fiscal federalism, resource control, regional autonomy, restructuring, etc. One thing that is clear from Kymlicka's thought is that ethnic group rights and the quest for cultural rights of nationalities within the nation should not be suppressed or ignored. The tendency on the part of many in public office especially when they are in the ruling party to silence or write off ethnic complaints or agitations of militant groups by simply saying, Nigeria must be one and there should be no opposing voice does not resolve any issue. While secession from the Nigerian federation should not be encouraged yet there can be grains of truth in calls for restructuring coming from all parts of the federation. The constant ethnic conflicts that take place among Hausas and Yoruba in the West, among Igbo and Hausa in the North, etc are signs that all is not well with the Nigerian federation.

This paper would love to argue also that beyond adequate recognition of ethnocultural rights in the framework of multicultural citizenship which implies here restructuring of the Nigerian federation for equity, fairness and just access of all citizens to the public good; Nigeria needs capable and ethical leaders who can take the nation to the land of Eldorado. Soniyi (2017) rightly notes that the challenges that Nigeria is facing are beyond restructuring. Perhaps one weakness of Kymlicka's thought is that he rarely highlights the problems of ethical leadership. No matter the kind of political community in which various ethnic groups live whether federalism, con-federalism, unitary state, etc; it is only when there are good and capable leaders that many tensions and agitations will be solved. The economic issue can be on the basis of many agitations. If people can find a good life and receive adequate economic benefits the ethnic agitations will be less. It is the view of this paper that Nigeria needs more than recognizing the rights of ethnocultural groups and restructuring the federation; it needs moral re-armament of all citizens particularly her leaders.

\section{CONCLUSION}

The goal of this paper was not to find any particular formula that will solve the national question in Nigeria. It was to highlight the fact that there are so many agitations in the land especially from various ethnocultural nationalities crying marginalization and deprivation of the full benefits of being citizens of Nigeria. The paper then examined the viewpoints of Will Kymlicka, a Canadian political philosopher on multicultural citizenship and minority rights. Through Kymlicka the paper argues that the voices of ethnocultural groups in Nigeria should not be silenced or ignored in the name of nation-building. A true federal formula has to be found that works towards genuine national integration and patriotism yet at the same time respect ethnocultural rights. In conclusion, this present author will love to share the sentiments of Kymlicka and Norman (2000) that recognizing minority rights of ethnic nations such as that of the Urhobo, Itsekiri, Ijaw, Isoko and others does not necessarily conflict with national citizenship; and that equally those who call for their minority rights should be mindful not to offend against the core ideals of civility and civic identity.

\section{REFERENCES}

Abercrombie, N., Hill, S., and Turner, B.S. (2000). The penguin dictionary of sociology. London: Penguin Books.

Ayoade, J. A. A. (1998). The federal character principle and the search for national integration. In K.Amuwo et. Al. (Ed.), Federalism and political restructuring in Nigeria, pp. 101-120. Ibadan: Spectrum Books Limited. 
Alubo, O. (2006). Ethnic conflicts and citizenship crises in the central region. Ibadan: Programme on Ethnic Federal Studies of the Department of Political Science of the University of Ibadan.

Beiner, R. (Ed.). (1995). Theorizing citizenship. Albany: State University of New York Press.

Bellamy. R. (2008). Citizenship: A very short introduction. Oxford: Oxford University Press.

Chaturvedi, A. K. (2006). Academic's dictionary of political science. New Delhi: Academic (India) Publishers.

Dukor, M. (2003). Ethnic nationalism and a theory of nation-building. In M. Dukor (Ed.), Philosophy and politics: Discourse on values, politics and power in Africa, pp.165-174. Lagos: Malthouse Press Limited.

Elaigwu, J. I. (2005). The politics of federalism in Nigeria. Jos: Aha Publishing House.

Falola, T. (2004). Ethnicity and Nigerian politics. In B Berman, D Eyoh and W Kymlicka (Ed.), Ethnicity and democracy in Africa, pp. 148-165. Oxford: James Currey.

Faulks, K. (2000). Citizenship. London: Routledge.

Ijaw Youths. (1998). Kaiama declaration. Accessed on 10 June 2017, from http://www.unitedijaw.com/kaiama.htm

Hoffman, J., and Graham, P. (2009). Introduction to political theory. Harlow, England: Pearson Educational Limited.

Johari, J. C. (2009). Principles of modern political science. New Delhi: Sterling Publishers Private Limited.

Johari, J. C. (2012). Contemporary political theory: New dimensions, basic concepts and major trends. New Delhi: Sterling Publishers Private Limited.

Kymlicka, W. (1995). Multicultural citizenship: A liberal theory of minority rights. Oxford: Clarendon Press.
Kymlicka, W. (2004). Nation-Building and minority rights: Comparing Africa and the West. In B Berman, D Eyoh and W Kymlicka (Ed.), Ethnicity and democracy in Africa, 54-71. Oxford: James Currey.

Kymlicka, W. (2010). Minority rights in political philosophy and international law. In S Besson and $\mathrm{J}$ Tasioolas (Ed.), The philosophy of international law, pp. 377-396. Oxford: Oxford University Press.

Kymlicka, W. (2010b). Ethnicity and liberalism in the USA. In M Guibernau and J Rex (Ed.), The ethnicity reader: Nationalism, multiculturalism and migration, pp. 255-272. Cambridge: Polity Press.

Kymlicka, W., and Norman, W. (2000). Citizenship in culturally diverse societies: Issues, contexts, concepts. In W. Kymlicka and W Norman (Ed.), Citizenship in diverse societies, pp. 1-41. Oxford: Oxford University Press.

Kymlicka, W., and Shapiro, I. (1997). Introduction. In I Shapiro and W Kymlicka (Ed.), Ethnicity and group rights, pp. 1-21. New York: New York University Press.

Mustapha, A. R. (2004). Ethnicity and politics of democratization in Nigeria. In B Berman, D Eyoh and W Kymlicka (Ed.), Ethnicity and democracy in Africa, pp.257-275. Oxford: James Currey.

Leinkoff, T.A., and Klusmeyer, d. (Ed.). (2001). Citizenship today; Global perspectives and practices. Washington, D.C.: Carnegie Endowment for International Peace.

Ogoni People. (1990). Ogoni bills of rights. Accessed on 10 June 2017, from http://www.bebor.org/wpcontent/uploads/2012/09/Ogoni-Bill-ofRights.pdf

Olawale, A. (1998). Federalism, inter-ethnic conflicts and the northernization policy of the 1950s and 1960s. In K Amuwo et. al., (Ed.), Federalism and political restructuring in Nigeria, pp. 50-63. Ibadan: Spectrum Books Limited. 
Oron Inidgenous Ethnic Linguistic Nationality. (1999). Oron bills of rights. Accessed on 10 June 2017, from http://www.waado.org/nigerdelta/Ri ghtsDeclaration/Oron.html

Pierik, R. (2013). Multiculturalism. In H LaFollette (Ed.), The international encyclopedia of ethics: Volume VI, pp. 3470-3480. Malden, MA: WileyBlackwell.

Rodrigues, L. C. (2017). Multiculturalism. Internet Encyclopedia of Philosophy. Accessed on 10 June 2017, from http://www.iep.utm.edu/multic $\mathrm{ul} / \# \mathrm{H} 2$

Roy, A. (2008). Citizenship. In Political theory: An introduction, R Bhargava and A Acharya (Ed.), pp.130-147. New Delhi: Pearson.

Shafir, G. (Ed.). (1998). The citizenship debate. Minneapolis: University of Minnesota Press.

Shapiro, I., and W Kymlicka. (Ed.). (1997). Ethnicity and group rights. New York: New York University Press.

Soniyi, (2017). Beyond Restructuring of the Nigerian State. https://www.thisdaylive.com/index.php/2017/0 3/27/beyond-restructuring-of-the-nigerian-state/

Song, Sarah, "Multiculturalism", The Stanford Encyclopedia of Philosophy (Spring 2017 Edition), Edward N. Zalta (ed.), URL = $<$ https://plato.stanford.edu/archives/spr2017/ent ries/multiculturalism/>.

Taylor, C. (1992). The politics of recognition. In C Taylor et. Al. (Ed.), Multiculturalism and 'the politics of recognition,' pp. 25-73. Princeton, NJ: Princeton University Press.

Uroh, C.O. (1998). On the ethics of ethnic balancing in Nigeria: Federal character reconsidered. In $\mathrm{K}$ Amuwo et. al. (Ed.), Federalism and political restructuring in Nigeria, pp. 191-200. Ibadan: Spectrum Books Limited. 